\title{
Oxytocin and Serotonin Brain Mechanisms in the Nonhuman Primate
}

\author{
Didhur Lefevre, ${ }^{1,2}$ Nathalie Richard, ${ }^{1}$ Mina Jazayeri, ${ }^{1}$ Pierre-Aurélien Beuriat, ${ }^{1}$ Sylvain Fieux, ${ }^{2}$ Luc Zimmer, ${ }^{2,3}$ \\ Jean-René Duhamel, ${ }^{1,2}$ and Angela Sirigu ${ }^{1,2}$ \\ ${ }^{1}$ Institut des Sciences Cognitives Marc Jeannerod, Centre National de la Recherche Scientifique, Unité Mixte de Recherche 5229, 69675 Bron, France, \\ ${ }^{2}$ Université Claude Bernard Lyon 1, Université de Lyon, 69000, France, and ${ }^{3}$ Centre d’Exploration et de Recherche Médicale par Emission de Positons, \\ Bioran, Bron 69675, France
}

Oxytocin (OT) is increasingly studied for its therapeutic potential in psychiatric disorders, which are associated with the deregulation of several neurotransmission systems. Studies in rodents demonstrated that the interaction between OT and serotonin (5-HT) is critical for several aspects of social behavior. Using PET scan in humans, we have recently found that 5 -HT $1 \mathrm{~A}$ receptor $\left(5-\mathrm{HT}_{1 \mathrm{~A}} \mathrm{R}\right)$ function is modified after intranasal oxytocin intake. However, the underlying mechanism between OT and 5-HT remains unclear. To understand this interaction, we tested 3 male macaque monkeys using both $\left[{ }^{11} \mathrm{C}\right] \mathrm{DASB}$ and $\left[{ }^{18} \mathrm{~F}\right] \mathrm{MPPF}$, two PET radiotracers, marking the serotonin transporter and the $5-\mathrm{HT}_{1 \mathrm{~A}} \mathrm{R}$, respectively. Oxytocin ( $1 \mathrm{IU}$ in $20 \mu \mathrm{l}$ of ACSF) or placebo was injected into the brain lateral ventricle $45 \mathrm{~min}$ before scans. Additionally, we performed postmortem autoradiography. Compared with placebo, OT significantly reduced $\left[{ }^{11} \mathrm{C}\right] \mathrm{DASB}$ binding potential in right amygdala, insula, and hippocampus, whereas $\left[{ }^{18} \mathrm{~F}\right] \mathrm{MPPF}$ binding potential increased in right amygdala and insula. Autoradiography revealed that $\left[{ }^{11} \mathrm{C}\right] \mathrm{DASB}$ was sensitive to physiological levels of 5-HT modification, and that OT does not act directly on the $5-\mathrm{HT}_{1 \mathrm{~A}} \mathrm{R}$. Our results show that oxytocin administration in nonhuman primates influences serotoninergic neurotransmission via at least two ways: (1) by provoking a release of serotonin in key limbic regions; and (2) by increasing the availability of $5-\mathrm{HT}_{1 \mathrm{~A}} \mathrm{R}$ receptors in the same limbic areas. Because these two molecules are important for social behavior, our study sheds light on the specific nature of their interaction, therefore helping to develop new mechanisms-based therapies for psychiatric disorders.

Key words: nonhuman primate; oxytocin; PET scan; serotonin

Significance Statement

Social behavior is largely controlled by brain neuromodulators, such as oxytocin and serotonin. While these are currently targeted in the context of psychiatric disorders such as autism and schizophrenia, a new promising pharmaceutical strategy is to study the interaction between these systems. Here we depict the interplay between oxytocin and serotonin in the nonhuman primate brain. We found that oxytocin provokes the release of serotonin, which in turn impacts on the serotonin $1 \mathrm{~A}$ receptor system, by modulating its availability. This happens in several key brain regions for social behavior, such as the amygdala and insula. This novel finding can open ways to advance treatments where drugs are combined to influence several neurotransmission networks.

\section{Introduction}

Oxytocin (OT) is a fascinating neurohormone because of the very wide range of actions it exerts at both the peripheral and the central level (McCall and Singer, 2012). As a consequence, this

\footnotetext{
Received March 9, 2017; revised May 31, 2017; accepted June 1, 2017.

Author contributions: A.L., J.-R.D., and A.S. designed research; A.L., M.J.,P.-A.B., and J.-R.D. performed research; A.L., S.F., and L.Z. performed autoradiography experiments; A.L., N.R., and P.-A.B. contributed unpublished reagents/analytic tools; A.L. and N.R. analyzed data; A.L., J.-R.D., and A.S. wrote the paper.

This work was supported by Centre National de la Recherche Scientifique and Labex Cortex University of Lyon I ("Investissement d'Avenir") Grant ANR-11-LABEX-0042 to A.S. and J.-R.D., A.L. was supported by a University of Lyon I fellowship, Labex Cortex Grant ANR-11-LABEX-0042. We thank Didier le Bars for access to the PET-scan facility; Jerome Redouté and Nicolas Costes for help during preliminary data analysis; and the staff at CERMEP for help during testing.

The authors declare no competing financial interests.
}

nonapeptide is being studied as a potential therapeutic molecule in various diseases (Altirriba et al., 2015; Feifel et al., 2016; Lefevre and Sirigu, 2016). The reason why OT is able to influence multiple processes, such as perception, reward, or pain processing (Young and Wang, 2004; Dölen et al., 2013; Marlin et al., 2015; Eliava et al., 2016; Oettl et al., 2016), is probably because of its modulatory effects on other neurotransmission systems, such as dopamine (Young and Wang, 2004; Baskerville and Douglas,

Correspondence should be addressed to either Dr. Lefevre Arthur or Dr. Sirigu Angela, 67 boulevard Pinel, 69675 Bron Cedex, France. E-mail: Arthur.lefevre@isc.cnrs.fr or sirigu@isc.cnrs.fr.

DOI:10.1523/JNEUROSCI.0659-17.2017

Copyright $\odot 2017$ the authors $\quad 0270-6474 / 17 / 376741-10 \$ 15.00 / 0$ 
2010) or the corticotrophin releasing factor (Dabrowska et al., 2011; Bosch et al., 2016).

Importantly, studies in rodents have shown that OT also enhances serotoninergic (5-HT) neurotransmission (Yoshida et al., 2009; Dölen et al., 2013; Pagani et al., 2015). We have recently confirmed in humans the existence of OT/5-HT interactions in brain in regions important for social cognition and emotions, notably in the amygdala, hippocampus, dorsal raphe nucleus (DRN), insula, and orbitofrontal cortex (OFC) using PET neuroimaging (Mottolese et al., 2014). A better understanding of such interactions could have important implications for clinical research as 5-HT is also a current therapeutic target for different psychiatric diseases (Bandelow et al., 2002; Celada et al., 2013; Vasa et al., 2014). In our study, intranasal OT administration increased 2'-Methoxyphenyl-(N-2'-pyridinyl)p-18F-fluoro-benzamidoethylpiperazine $\left(\left[{ }^{18} \mathrm{~F}\right] \mathrm{MPPF}\right)$ (a serotonin $1 \mathrm{~A}$ receptor $\left[5-\mathrm{HT}_{1 \mathrm{~A}} \mathrm{R}\right]$ radiotracer) nondisplaceable binding potential $\left(\mathrm{BP}_{\mathrm{ND}}\right)$, which suggests either a decreased serotonin concentration or an increased availability of 5- $\mathrm{HT}_{1 \mathrm{~A}}$ receptors. Because in studies on rodents, OT has been shown to increase serotonin concentration (Dölen et al., 2013), we proposed that the rise of $\mathrm{BP}_{\mathrm{ND}}$ we observed in humans could be the consequence of an externalization or a change of affinity of 5- $\mathrm{HT}_{1 \mathrm{~A}} \mathrm{R}$. However, using a single radiotracer (Mottolese et al., 2014), we were not able to firmly answer this question.

To test this hypothesis, we studied here macaque monkeys, allowing us to administer OT directly into the brain, thus avoiding criticisms associated with intranasal administration method (Leng and Ludwig, 2016). By showing that the intracerebroventricular injection of OT modulate central 5-HT, our result could further corroborate our previous findings in humans showing that intranasal OT also directly acts on brain 5-HT. Moreover, intracerebroventricular injection is a method that shows consistent and long-lasting effects on behavior (Pedersen et al., 1982) and brain activity (Febo and Ferris, 2014). Finally, it is possible to repeat PET scan acquisitions in macaque monkeys within a short time frame and use different tracers, unlike in humans where dosimetric issues arise.

To further investigate the effects of OT on 5-HT neurotransmission, we performed a PET scan experiment where we combined two radiotracers, $\left[{ }^{11} \mathrm{C}\right] \mathrm{N}, \mathrm{N}$-dimethyl-2-(2amino-4-cyanophenylthio)benzylamine ([ $\left.\left.{ }^{11} \mathrm{C}\right] \mathrm{DASB}\right)$, a molecule binding to the serotonin transporter (SERT), and $\left[{ }^{18} \mathrm{~F}\right] \mathrm{MPPF}$, the $5-\mathrm{HT}_{1 \mathrm{~A}} \mathrm{R}$ marker. The aim was to track OTinduced changes at both the serotonin concentration (DASB) and the $5-\mathrm{HT}_{1 \mathrm{~A}}$ receptor levels (MPPF). This design thus provides a fuller picture of the OT/5-HT interaction in the primate brain, as both SERT and 5- $\mathrm{HT}_{1 \mathrm{~A}} \mathrm{R}$ are widespread across the brain and involved in social behavior regulation (Hamon et al., 1990).

Our predictions were that OT would induce (1) an increase of MPPF $\mathrm{BP}_{\mathrm{ND}}$ in limbic regions associated with socioemotional behaviors, as in humans, and (2) a decrease of DASB BP ${ }_{\mathrm{ND}}$ consistent with an increase of 5-HT concentration in the same regions (Lundquist et al., 2007). Such a pattern of results would imply that OT induces 5-HT release in the primate brain, which in turn acts on $5-\mathrm{HT}_{1 \mathrm{~A}} \mathrm{R}$ functioning. Our regions of interest (ROIs) were those in which we previously found an effect of OT on 5-HT neurotransmission, namely, the amygdala, hippocampus, insula, DRN, and OFC (Mottolese et al., 2014). In addition to the in vivo PET-scan experiment, we ran in vitro autoradiography experiments to explore the sensitivity of DASB and MPPF to OT and 5-HT, to further corroborate the mechanisms of OT/ 5-HT interaction unrevealed in vivo.

\section{Materials and Methods}

\section{Experimental design}

Animals. The experiment and all of the involved procedures were approved by the local animal ethical committee CELYNE 42 (reference 02075-01) and the French Ministry of agriculture and environment and used experimental procedures complying with the recommendations of the local authorities on animal care (Direction Départementale des Services Vétérinaires, Lyon, France) and the European Community standards for the care and use of laboratory animals. Three rhesus macaques (Monkeys V, P, and J) were housed together at the Institut des Sciences Cognitives Marc Jeannerod (Bron, France). Subjects were all males (mean age $=4.1$ years, mean weight $=5.8 \mathrm{~kg}$ ), obtained from SILABE. These monkeys were kept under standard conditions ( $12 \mathrm{~h}$ light cycles, $23^{\circ} \mathrm{C}$ and $50 \%$ humidity), were fed with monkey chow, vegetables, and fresh fruits, had ad libitum access to water, and enrichments were regularly offered (boxes and puzzles containing dry fruit, at least once per week) following recommendations from our own laboratory animal welfare committee. Daily clicker training ensured monkeys' cooperation for various procedures (going in the contention chair, head fixation habituation, anesthesia procedure, etc.).

Protocol. Because of the existence of a diurnal rhythm of OT concentration in the CSF (Amico et al., 1989), PET scans always took place between 12:00 noon and 4 P.M. No more than one scan per week was performed on the same monkey, and a strict minimum of at least $5 \mathrm{~d}$ was observed between two scans.

Monkeys were isolated from cage mates, and food was removed on the evening before the scan, but still had ad libitum access to water. They were anesthetized with Zoletil (tiletamine/zolazepam, Virbac $15 \mathrm{mg} / \mathrm{kg}$ ) 90 $\min (86.7 \pm 16.6 \mathrm{~min})$ before the beginning of the scan. The dose of Zoletil depended on monkeys' weight and consciousness state. It should be noted that Zoletil does not alter serotonergic PET scan binding, at least for the transporter (no studies so far on the 5- $\mathrm{HT}_{1 \mathrm{~A}} \mathrm{R}$ ) (Elfving et al., 2003; Yamanaka et al., 2014). The consciousness state of the monkey was monitored by a trained experimenter during the whole testing, and an additional Zoletil dose was administered when required (usually just before the beginning of the scan, mean total dose $=130 \mathrm{mg}$ ). A catheter was installed on the saphenous vein, and Ringer's liquid was administered throughout the experiment. The chamber was cleaned, and lidocaine was sprayed on the tissue. After rinsing with physiological saline, OT or placebo was injected in the right lateral ventricle $\sim 45$ min before the PET examination $($ mean $=47.6 \pm 6.9 \mathrm{~min})$. This delay was similar to our previous experiment in humans and the minimum possible amount of time between intracerebroventricular injection and PET scan start. We chose to inject in the right hemisphere because the OT effects were found lateralized in humans (Mottolese et al., 2014), although our injections should rapidly diffuse to the contralateral hemisphere due to the CSF flow. Then, the animal was taken to the imaging center (Centre d'Exploration et de Recherche Médicale par Emission de Positons [CERMEP]) and installed in a stereotaxic frame (lidocaine and ocular gel were applied to ears and eyes to prevent any discomfort), the cardiac rhythm and $\mathrm{O}_{2}$ saturation were monitored during the scanning, and wool covers prevented body temperature to diminish. A 1 min low-dose CT scan was performed to measure tissue and head support attenuation. At the end of the scan, the monkey was brought back to the laboratory and put back into its home cage with a heat lamp. Depending on its state, food was provided or not before the lights turned off (8:00 P.M.). The monkey was reunited with its cage mate on the morning after.

In total, 30 scans were performed (Monkeys $\mathrm{V}$ and J: 3 MPPF under OT, 3 MPPF under placebo, 3 DASB under OT, 3 DASB under placebo; Monkey P: 2 MPPF under OT, 2 MPPF under placebo, 1 DASB under OT, 1 DASB under placebo). The unequal number of scans for each monkey was taken into account in the SPM design; all data were put in a flexible factorial design with a treatment effect, moderated by a subject factor (see Statistical analyses).

\section{Surgical procedure}

Each monkey underwent two surgeries. Both were performed in a fully sterile environment. Anesthesia was induced with ketamine (Virbac 10 

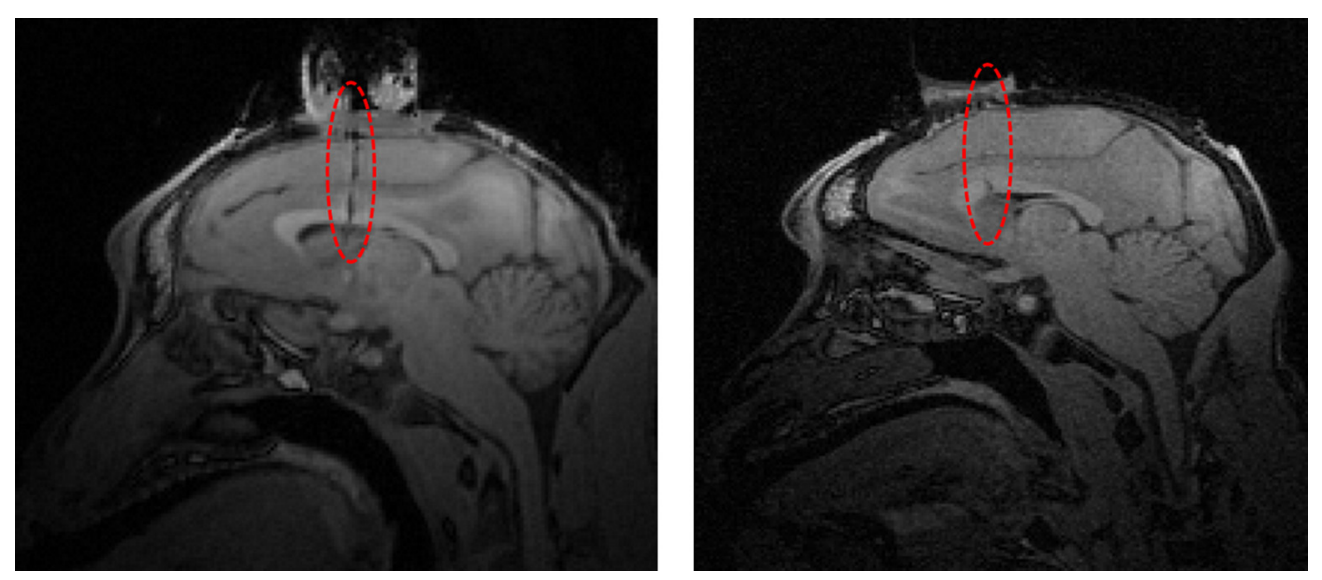

Figure 1. Anatomical MRI from Monkey V (left) and Monkey J (right) at the end of the experiment. Red ellipse indicates the path of the needle.

$\mathrm{mg} / \mathrm{kg}$ ) and maintained with isoflurane (1\%-2\%). After each surgery, monkeys received appropriate antibiotic coverage and pain relievers as needed (buprenorphine). At least 1 month was given to the monkey to fully recover.

During the first surgery, animals were implanted with an MRIcompatible head-restraint post using standard techniques (dental acrylic, titanium and ceramic screws). In the second procedure, once the monkey was habituated to head fixation, a chronic injection chamber (plastic) was implanted, to allow descending an injection needle into the brain. This chamber was cleaned with oxygenated water, betadine, and physiologic serum at least twice per week in a contention chair with the head fixed.

\section{Intracerebroventricular injections}

For each monkey, we first precisely localized the right lateral ventricle, guided by structural MR images, by sampling $200 \mu \mathrm{l}$ of CSF to confirm our needle was in the ventricle. This procedure was done in awake animals under head restraint conditions. These samples were used for chemical assays in another study (A.L., manuscript in preparation). It would have been interesting to measure OT concentration in CSF at baseline and after the intracerebroventricular injection. Unfortunately, after injection, constraints linked to practical procedures (moving from the laboratory to the neuroimagery center) and those concerning the limited effects of OT in time did not allow us to undertake this measurement.

On the day of scanning, a 23 Gauge needle (Terumo), already filled with the solution (artificial CSF, Harvard Apparatus; or OT, SigmaAldrich) diluted in ACSF), attached to a $100 \mu \mathrm{l}$ microsyringe (Hamilton) was descended at $50 \mu \mathrm{m} / \mathrm{s}$ to the location previously identified as the right lateral ventricle, with a hydraulic microdrive (Narishige). The repeatability of this manipulation was ensured using a rigid nylon grid fitted to the chamber (Crist Instruments) oriented in the exact same manner every time. For each monkey, the same grid's hole was used throughout the experiment. Once the correct depth was reached, $20 \mu \mathrm{l}$ of solution was manually injected over $5 \mathrm{~min}$, to allow the ventricle to adapt to the incoming liquid. OT and placebo were injected in a random order in each monkey. To our knowledge, this is the first study using OT intracerebroventricular in macaque monkeys. The dosage of $1 \mathrm{IU}(\sim 2 \mu \mathrm{g}$ of OT) was chosen based on the rodent literature because it produced observable brain effects using fMRI (Febo and Ferris, 2014). Also, a recent study in macaques using a similar dose found effects of OT following injection in the amygdala (Chang et al., 2015). Our goal was to obtain the minimal effective dose, to avoid stimulation of vasopressin receptors. Anatomical MR images were used to check the path of the needle (Fig. 1).

\section{Anatomical MRI}

Each monkey underwent at least two anatomical MRI: one before the chamber implantation, to precisely localize the right lateral ventricle, and one after the surgery, to verify the position of the chamber and estimate the depth that needed to be reached. Additionally, Monkeys V and J underwent a third anatomical MRI to check the path of the injection needle after the end of experiments (Fig. 1).

The anatomical scans were performed at the imaging center (CERMEP) on a (1.5-T MR scanner Sonata; Siemens) with a radial receive-only surface coil $(10 \mathrm{~cm}$ diameter $)$ placed around the monkey's head post, and consisted in a T1-3D MPRAGE sequence (repetition time $2160 \mathrm{~ms}$; echo time $2.89 \mathrm{~ms}$; inversion time $1100 \mathrm{~ms} ; 176$ sagittal slices; $0.6 \times 0.6 \times 0.6 \mathrm{~mm}$ voxels).

\section{PET scan}

PET scans were acquired on a Biograph mCT PET/CT tomograph (Siemens) at the imaging center (CERMEP). We used MPPF to map the $5-\mathrm{HT}_{1 \mathrm{~A}} \mathrm{R}$.

A dynamic emission scan was acquired in list mode during $90 \mathrm{~min}$ for DASB, and $70 \mathrm{~min}$ for MPPF, after radiotracer injection. A total of 30 (DASB) or 24 (MPPF) frame images were reconstructed by using the 3D-ordinary Poisson-ordered subset expectation maximization iterative algorithm incorporating PSF and time of flight (with an All Pass filter) after correction for scatter and attenuation as well as a transversal zoom factor of eight $\left[256 \times 256\right.$ voxels in-plane $\left(0.4 \mathrm{~mm}^{2}\right)$ and 109 slices $(2.03 \mathrm{~mm}$ thickness)]. The resolutions for reconstructed images were $\sim 2.6 \mathrm{~mm}$ in FWHM in the axial direction and $3.1 \mathrm{~mm}$ in FWHM in the transaxial direction for a source located $1 \mathrm{~cm}$ from the field of view.

$D A S B$. DASB was synthetized on site, with a mean specific activity of $1.22 \pm 0.66 \mathrm{Ci} / \mu \mathrm{mol}$. A bolus of $\left[{ }^{11} \mathrm{C}\right] \mathrm{DASB}$ was injected (mean injected dose, $4.31 \pm 0.45 \mathrm{mCi}$ )

MPPF. MPPF was obtained by nucleophilic fluoration of a nitro precursor (Le Bars et al., 1998), with a radiochemical yield of 20\%-25\% at the end of the synthesis and a mean specific activity of $4.41 \pm 1.86$ $\mathrm{Ci} / \mu \mathrm{mol}$. A bolus of $\left[{ }^{18} \mathrm{~F}\right] \mathrm{MPPF}$ was injected (mean injected dose, $4.16 \pm 0.52 \mathrm{mCi}$ ). It is an antagonist to $5-\mathrm{HT}_{1 \mathrm{~A}} \mathrm{R}$ with a binding affinity of $2.8 \mathrm{nM}$.

\section{Autoradiography}

Adjacent coronal right hemisphere brain slices from a male macaque containing the hippocampus were defrosted from the CERMEP database. They were then incubated for $20 \mathrm{~min}$ in Tris PBS (TBS) buffer (Sigma, with $\mathrm{Ca}^{2+}$, $\mathrm{pH}$ adjusted to 7.5$)$ containing $1 \mu \mathrm{Ci} / \mathrm{ml}$ of $\left[{ }^{18} \mathrm{~F}\right] \mathrm{MPPF}$ or $\left[{ }^{11} \mathrm{C}\right] \mathrm{DASB}$. For MPPF, increasing amounts of OT (Sigma-Aldrich) were then added $(0,5$, $100,2000 \mathrm{ng}$ ), and for DASB, different physiologic concentrations of 5-HT (Sigma) were added $(0,5,25,75,150 \mathrm{~nm})$. Notably, the incubation duration did not last $45 \mathrm{~min}$ because we do not expect mid- or long-term modifications in dead tissue.

After incubation, slices were rinsed in TBS $+\mathrm{Ca}^{2+}$ for $1.5 \mathrm{~min}$ and purified water for $1.5 \mathrm{~min}$, then dried and juxtaposed to a phosphor imaging plate for $60 \mathrm{~min}$ (BAS-5000, Fujifilm). All films were analyzed by a computer-assisted image analysis system (MultiGauge, Fujifilm) and 
drawn manually from our ROI, the hippocampus, according to a macaque brain atlas (Paxinos et al., 2000). This area was chosen because it is rich in both OT receptors, SERT and $5-\mathrm{HT}_{1 \mathrm{~A}} \mathrm{R}$ and given that this is also the region where we previously observed OT/5-HT functional interaction (Mottolese et al., 2014). Quantification of labeling was done by measuring photo stimulated luminescence (PSL), in the hippocampus. All conditions were run in duplicate.

\section{Data processing}

For each monkey, respective PET scans and anatomical MRI were registered linearly using the Minc ToolKit (http://bic-mni.github.io/) (Collins et al., 1994). For each PET scan, the frames were summed to obtain one image per session. These images were registered for each radiotracer on a reference chosen for its high raw activity. Then, the mean PET, per monkey and per radiotracer, was computed and a second registration of each PET on this average was done. The mean images of both radiotracers were registered on each monkey anatomical MRI.

To perform comparisons between our 3 monkeys and to overlap ROIs provided by the atlas with our scans, the transformation between each monkey space and a common macaque brain template (Ballanger et al., 2013) was also computed. Individual anatomical MRI were nonlinearly registered on the template using FNIRT (FSL, http://fsl.fmrib.ox.ac.uk/fsl/).

We used a simplified reference tissue model to compute $\mathrm{BP}_{\mathrm{ND}}$, with cerebellum (minus the vermis) as the reference region for DASB and white matter of the cerebellum as the reference region for MPPF. These regions were defined from the atlas registered on the template (Ballanger et al., 2013). Regional parametric values were obtained by modeling of the mean regional kinetics, extracted in the native PET spaces inside ROIs from the atlas registered to each monkey space using the inverse of nonlinear transformation computed previously; these ROI values were used for the inter-regions correlations. Whole-brain parametric images were obtained by modeling the voxel kinetics. Resulting parametric images were then nonlinearly transformed to the common template space for further voxel-based SPM analyses.

\section{Statistical analyses}

If not otherwise specified, all analyses were performed with SPM12 and STATISTICA 8.

\section{PET scan data}

For DASB, we also used a flexible factorial design, with a subject factor, to test the effects of treatment (OT vs placebo) on DASB $\mathrm{BP}_{\mathrm{ND}}$. Proportional scaling was applied to account for the observed interscan variability and to reduce the differences of gain sensitivity between each $\left[{ }^{11} \mathrm{C}\right] \mathrm{DASB}$ scan. Global measurements were sensitive to this gain effect; and because we could not rely on already existing $\left[{ }^{11} \mathrm{C}\right] \mathrm{DASB}$ data from human experiments, we used a conservative statistical threshold $(p<$ 0.0001 , uncorrected). This design was not restricted to our ROI but applied to the whole brain as we know there are differences between the distribution of serotonin transporter and $5-\mathrm{HT}_{1 \mathrm{~A}} \mathrm{R}$ (Savli et al., 2012). Moreover, this contrast was limited to voxels in which the binding potential was superior to $0.2\left(\mathrm{a} \mathrm{BP} \mathrm{ND}_{\mathrm{N}}<0.2\right.$ does not represent a significant concentration of serotonin transporter).

For MPPF, we reproduced the same analysis than in our human study (Mottolese et al., 2014). A flexible factorial design $(p<0.01$, uncorrected), with a subject factor, testing the effects of treatment (OT vs placebo) on MPPF $\mathrm{BP}_{\mathrm{ND}}$ with an ANCOVA by subject to account for the observed intersubject variability (as opposed to the global gain effect observed with [ $\left.\left.{ }^{11} \mathrm{C}\right] \mathrm{DASB}\right)$, restricted to our ROI by an inclusive mask containing amygdala, hippocampus, insula, and prefrontal cortex (same mask as in Mottolese et al., 2014). We also computed raw BP variations from the clusters (SPM12, extracted from SPM, http://www.fil.ion.ucl.ac.uk/spm/), values were divided by the monkey mean value to account for interindividual variability and transformed in percentage to compare with the variations obtained in humans. Moreover, this contrast was limited to voxels in which the binding potential was superior to $0.2\left(\mathrm{a} \mathrm{BP} \mathrm{ND}_{\mathrm{N}}<0.2\right.$ does not represent a significant concentration of $\left.5-\mathrm{HT}_{1 \mathrm{~A}} \mathrm{R}\right)$.

In humans, we found that, after OT administration, the mean MPPF $\mathrm{BP}_{\mathrm{ND}}$ in the amygdala was correlated with other regions (hippocampus, insula, OFC, and anterior cingulate gyrus) influenced by OT (Mottolese et al., 2014). Thus, we performed correlation tests between the mean amygdala MPPF $\mathrm{BP}_{\mathrm{ND}}$ (ROI extracted from the atlas) and the mean MMPF BP ${ }_{\mathrm{ND}}$ of these regions. We tested correlations with both Pearson and Spearman's rank tests, corrected for multiple comparisons with Bonferroni's correction $\left(\mathrm{p}_{\text {corrected }}<0.0125\right)$, because of the low number of data $(n=8)$, to reject positive results due to potential outliers.

\section{Results}

A total of 30 PET scans were performed $\left(16\left[{ }^{18} \mathrm{~F}\right] \mathrm{MPPF}\right.$ and 14 $\left.\left[{ }^{11} \mathrm{C}\right] \mathrm{DASB}\right)$ in three monkeys. Each individual underwent an equal number of sessions after intracerebroventricular injection of placebo (ACSF) and OT (1 IU).

\section{OT modulates [ ${ }^{11} \mathrm{C}$ ]DASB binding potential}

Using a whole-brain voxel-based analysis, we found a significant effect of treatment (OT < placebo) on $\left[{ }^{11} \mathrm{C}\right] \mathrm{DASB} \mathrm{BP}_{\mathrm{ND}}$, in several clusters located in the right amygdala, the right insula, the right hippocampus, and the temporal cortex (Fig. 2). For a complete list of significant clusters, see Table 1 . All of these clusters resisted FWE correction $\left(p_{\mathrm{FWE}}<0.05\right)$. No significant changes were found in the left hemisphere. The opposite contrast (placebo $<$ OT) did not yield significant differences (no significant voxels). There were no effects of anesthetic dosage or scanning starting time.

\section{OT modulates $\left[{ }^{18} \mathrm{~F}\right] \mathrm{MPPF}$ binding potential}

We measured OT-induced effect on $\left[{ }^{18} \mathrm{~F}\right] \mathrm{MPPF} \mathrm{BP}_{\mathrm{ND}}$ using SPM voxel-based analysis, with a mask encompassing the regions found in our previous study (amygdala, hippocampus, insula, raphe nuclei, OFC), identified from a macaque atlas (Ballanger et al., 2013). We found a significant effect of treatment condition $\left(\mathrm{OT}>\right.$ placebo) on $\left[{ }^{18} \mathrm{~F}\right] \mathrm{MPPF} \mathrm{BP}_{\mathrm{ND}}$, in two clusters located again in the right amygdala $(k=76)$ and in the right insula $(k=$ 491) (Fig. 3). The mean $\mathrm{BP}_{\mathrm{ND}}$ values extracted from these clusters indicated that $\mathrm{OT}$ increased $\left[{ }^{18} \mathrm{~F}\right] \mathrm{MPPF} \mathrm{BP}_{\mathrm{ND}}$ by $33.3 \%$ in the amygdala and by $32.8 \%$ in the insula (Fig. 3). There were no effects of anesthesia (Zoletil dose) or scanning starting time. The opposite contrast (placebo $>$ OT) did not lead to any significant differences (no significant voxels). There were no effects of anesthesia (Zoletil dose) or scanning starting time.

\section{Between region correlations of $\mathrm{MPPF} \mathrm{BP}_{\mathrm{ND}}$ after OT}

Given that the amygdala is a major target of OT effects as shown by previous studies (Sripada et al., 2013; Mottolese et al., 2014; Kovács and Kéri, 2015), we searched for a potential $\left[{ }^{18} \mathrm{~F}\right] \mathrm{MPPF}$ $\mathrm{BP}_{\mathrm{ND}}$ correlation between this region and other $5-\mathrm{HT}_{1 \mathrm{~A}} \mathrm{R}$ modulated sites. We extracted the mean regional $\left[{ }^{18} \mathrm{~F}\right] \mathrm{MPPF}$ $\mathrm{BP}_{\mathrm{ND}}$ values from each ROI (amygdala, hippocampus, insula, raphe nuclei, and OFC) based on a macaque atlas (Ballanger et al., 2013). Using both Pearson and Spearman correlation tests (see Materials and Methods), we found that, after OT treatment, the right amygdala significantly correlated with the insula, the raphe nuclei, and the OFC ( $p<0.0125$; Table 2$)$. No significant correlations were found under placebo (all $p$ values $>0.0125$; Table 2 ).

\section{In vitro modulation of $\left[{ }^{11} \mathrm{C}\right] \mathrm{DASB}$ and $\left[{ }^{18} \mathrm{~F}\right] \mathrm{MPPF}$ binding potential}

To further understand the in vivo results obtained so far, we needed to check the sensitivity of the $\left[{ }^{11} \mathrm{C}\right] \mathrm{DASB}$ ligand to endogenous 5-HT concentrations. Moreover, it was equally important to verify whether a direct action of OT on the $5-\mathrm{HT}_{1 \mathrm{~A}} \mathrm{R}$ was possible. 

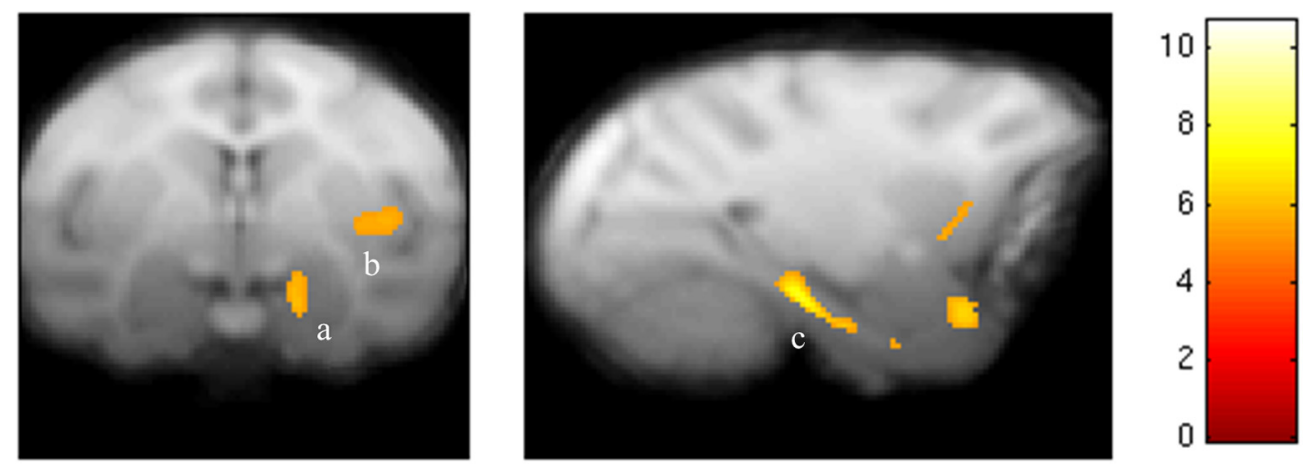

T score

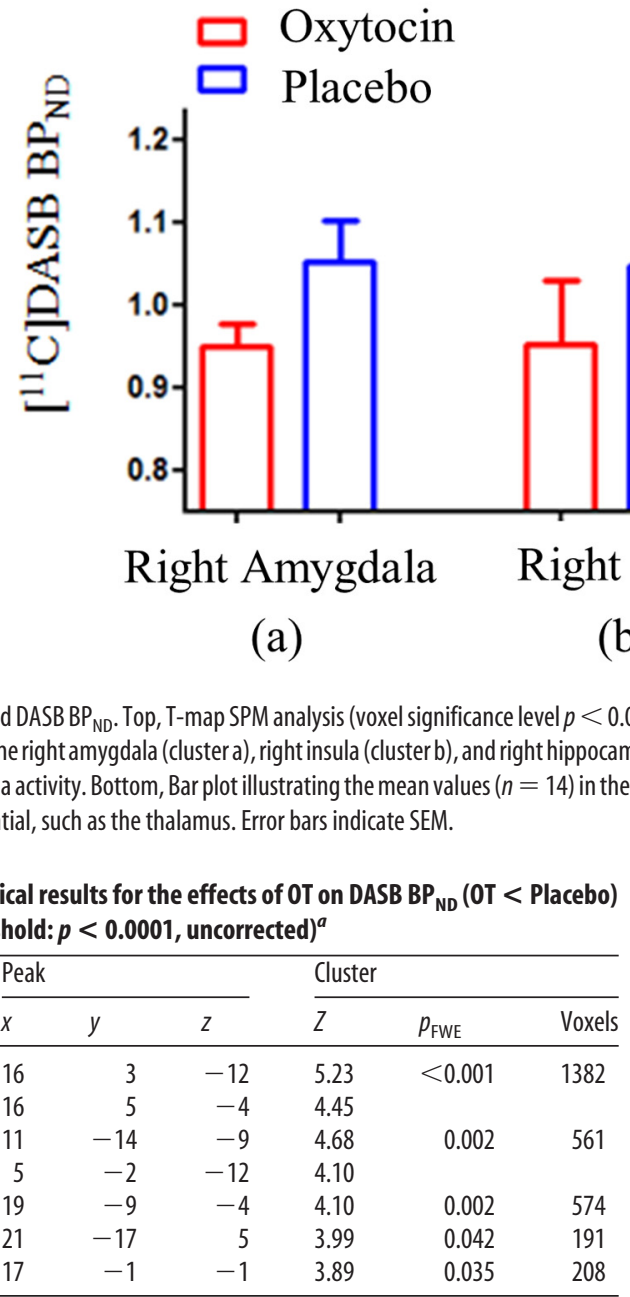

${ }^{a}$ All significant clusters $(p<0.05)$ were located in the right hemisphere.

We thus tested whether $\left[{ }^{11} \mathrm{C}\right]$ DASB labeling of the serotonin transporter was receptive to serotonin concentration. We found a dose-dependent effect of serotonin on $\left[{ }^{11} \mathrm{C}\right] \mathrm{DASB}$ labeling, which decreased in inverse proportion to the concentration of serotonin present during incubation (Fig. 4). This result is similar to what we observed in vivo with PET scan, except the cause was different. Moreover, the PSL values in the hippocampus, our reference region rich in serotonin transporter, were also found to decrease according to the serotonin dose. More precisely, the $5 \mathrm{~nm}$ serotonin dose, which represents baseline levels, did not affect $\left[{ }^{11} \mathrm{C}\right]$ DASB labeling, but higher doses, which are in the range of in vivo endogenous serotonin release, reduced PSL value (Fig. 4). No- tably, serotonin doses of 25,75 , and $150 \mathrm{~nm}$ did not differ each other, thus suggesting a potential ceiling effect. Finally, there were no variations of $\left[{ }^{11} \mathrm{C}\right] \mathrm{DASB}$ labeling between duplicate slices.

We also tested whether OT could act directly on the $5-\mathrm{HT}_{1 \mathrm{~A}} \mathrm{R}$ by incubating brain slices with $\left[{ }^{18} \mathrm{~F}\right] \mathrm{MPPF}$ and OT, under different dosages ( $0 \mathrm{ng}, 5 \mathrm{ng}, 100 \mathrm{ng}, 2 \mu \mathrm{g}$ ), the $2 \mu \mathrm{g}$ dose being the one we injected intracerebroventricularly. We did not find any $\left[{ }^{18} \mathrm{~F}\right] \mathrm{MPPF}$ labeling differences between the control slice (no OT) and any of the OT conditions (Fig. 5), contrary to what we observed in vivo with PET-scan imaging, suggesting that OT does not act directly on $5-\mathrm{HT}_{1 \mathrm{~A}} \mathrm{R}$. There were no variations of $\left[{ }^{18} \mathrm{~F}\right] \mathrm{MPPF}$ labeling between duplicate slices.

\section{Discussion}

We found that OT directly injected into the lateral ventricle decreased the binding $\left(\mathrm{BP}_{\mathrm{ND}}\right)$ of $\left[{ }^{11} \mathrm{C}\right] \mathrm{DASB}$ to the SERT and increased binding of $\left[{ }^{18} \mathrm{~F}\right] \mathrm{MPPF}$ to the $5-\mathrm{HT}_{1 \mathrm{~A}} \mathrm{R}$. These effects were observed in regions important for socioemotional functioning, namely, the amygdala, the insula, the hippocampus, the OFC, and the temporal cortex. Thus, the present experiment brings new and clear evidence that OT is modulating the serotonergic system in primates. Moreover, when looking at in vitro brain slices, we found that serotonin decreased $\left[{ }^{11} \mathrm{C}\right] \mathrm{DASB} \mathrm{BP}_{\mathrm{ND}}$ on the same slices, but that OT did not act directly on $\left[{ }^{18} \mathrm{~F}\right] \mathrm{MPPF}$ $\mathrm{BP}_{\mathrm{ND}}$. 


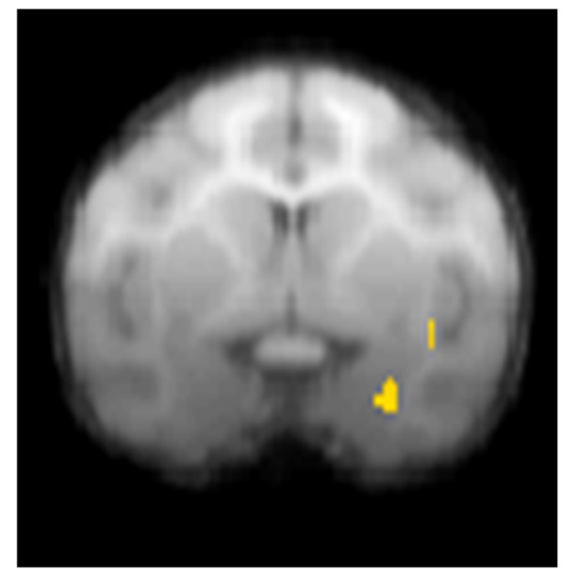

Right Amygdala

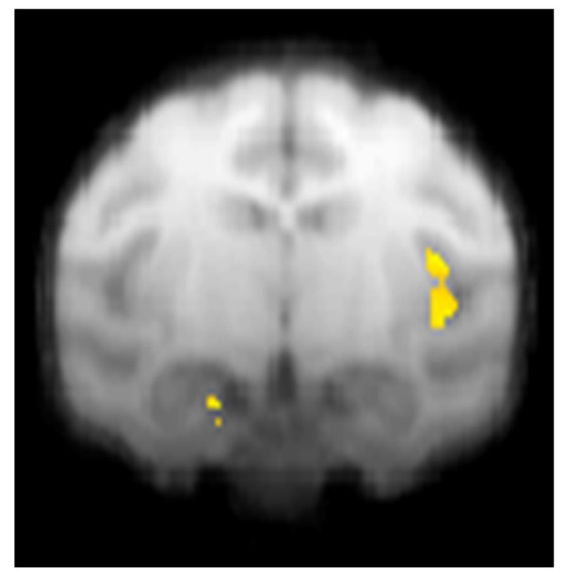

Right Insula

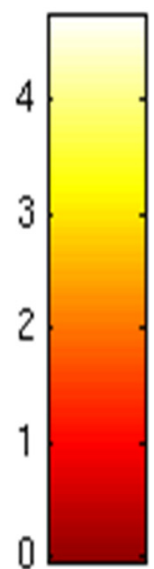

T score

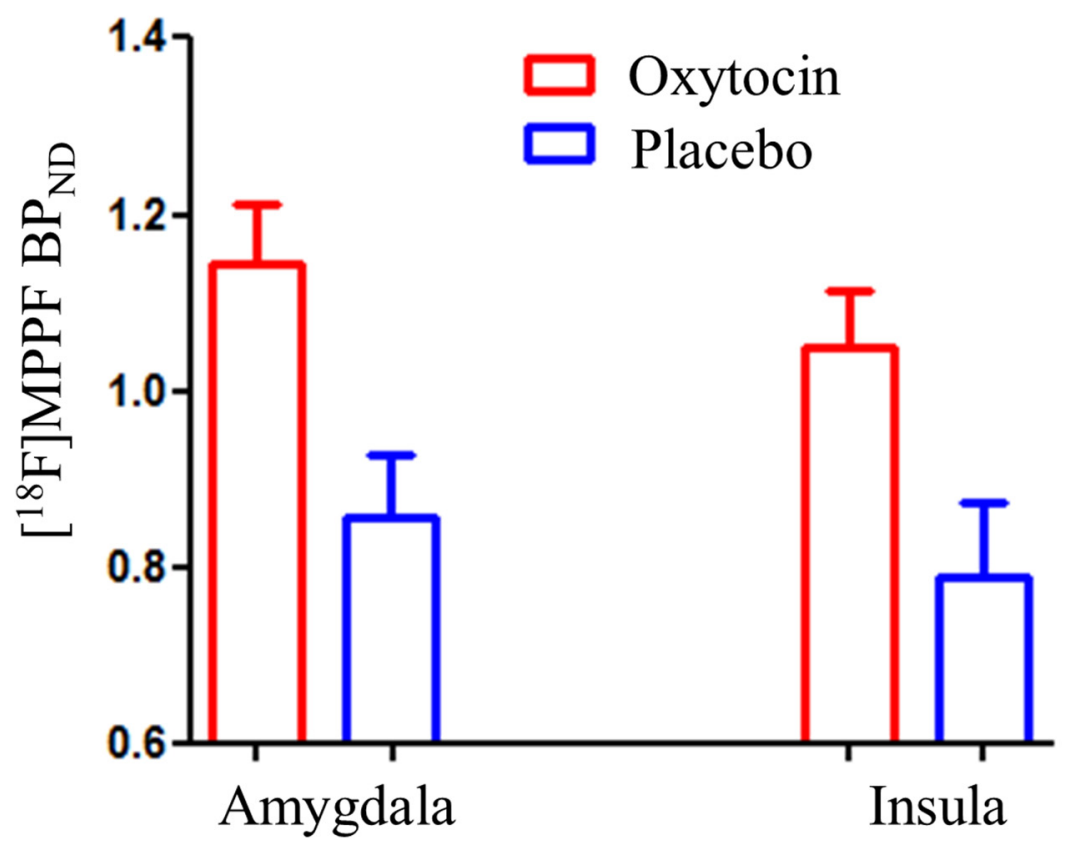

Figure 3. $0 \mathrm{~T}$ increases MPPF BP ${ }_{\mathrm{ND}}$. Top, T-map SPM analysis (voxel significance level $p<0.01$, uncorrected) showing the effects of OT on MPPF BP ${ }_{\mathrm{ND}}$ compared with placebo (OT $>$ placebo). Effects were localized in the right amygdala (left) and the right insula (right). Middle, Scale bar indicates T score. Bottom, Mean BP ${ }_{\mathrm{ND}}$ inside amygdala and insula clusters, for each scan ( $n=16$, extracted from SPM and normalized per individual). The average increase of $\mathrm{BP}_{\mathrm{ND}}$ after $0 \mathrm{~T}$ is $33.3 \%$ in the amygdala and $32.8 \%$ in the insula (compared with the $\sim 5 \%$ obtained in humans). Error bars indicate SEM.

Table 2. Coefficients of correlation between MPPF $B P_{\mathrm{ND}}$ in the amygdala and in other ROIs ${ }^{a}$

\begin{tabular}{lll}
\hline & Placebo & Oxytocin \\
\hline Right hippocampus & $R=0.71$ & $R=0.93^{*}$ \\
Right insula & Rho $=0.76$ & Rho $=0.79$ \\
& $R=0.81$ & $R=0.94^{*}$ \\
Right 0FC & Rho $=0.62$ & Rho $=1.00^{*}$ \\
& $R=0.93^{*}$ & $R=0.98^{*}$ \\
Right ACC & Rho $=0.60$ & Rho $=1,00^{*}$ \\
& $R=0.58$ & $R=0.87^{*}$ \\
& Rho $=0.58$ & Rho $=0.90^{*}$ \\
\hline
\end{tabular}

${ }^{a} \mathrm{R}$, Pearson's correlation; Rho, Spearman's rank correlation.

*Significant $p$ values after correction for multiple comparisons $(p<0.0125)$.
It should be noted that we observed effects in regions that have already been reported to be affected by exogenous OT. A recent review of fMRI studies showed that OT consistently modulates the human amygdala and the insula (Wigton et al., 2015). Moreover, amygdala, hippocampus, and prefrontal cortex have also been found to be influenced by OT in experiments on rodents (Viviani et al., 2011; Knobloch et al., 2012; Owen et al., 2013; Nakajima et al., 2014). Thus, our results are coherent with the literature from both animal and human experiments in regard of the localization of OT effects in the brain. It is also important to note that, in the amygdala and insula, we obtained results with both $\left[{ }^{11} \mathrm{C}\right] \mathrm{DASB}$ and $\left[{ }^{18} \mathrm{~F}\right] \mathrm{MPPF}$, showing the strength of our approach. Furthermore, we found that, only following OT administration, MPPF binding potential among regions included in this socioemotional network was highly correlated, thus showing the coordinative role of OT within this corticolimbic serotonergic system. 


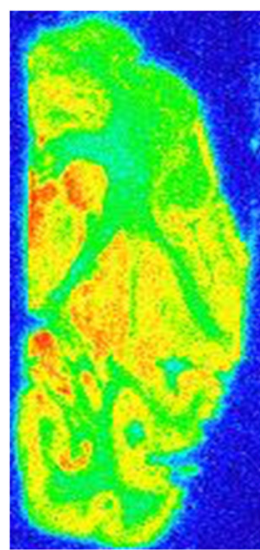

Control

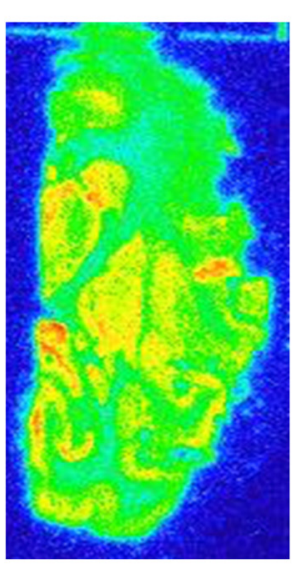

$150 \mathrm{nM}$

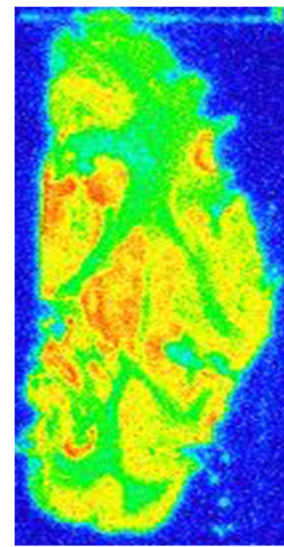

$5 \mathrm{nM}$

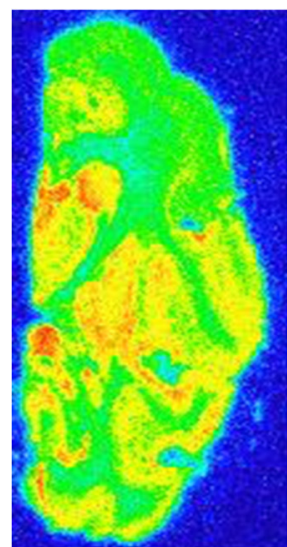

$25 \mathrm{nM}$

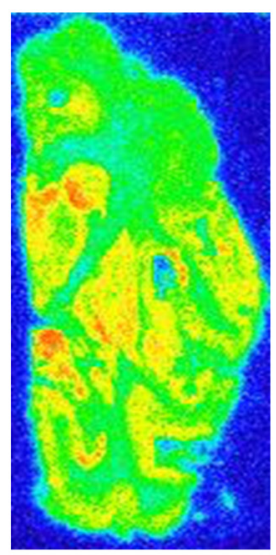

$75 \mathrm{nM}$
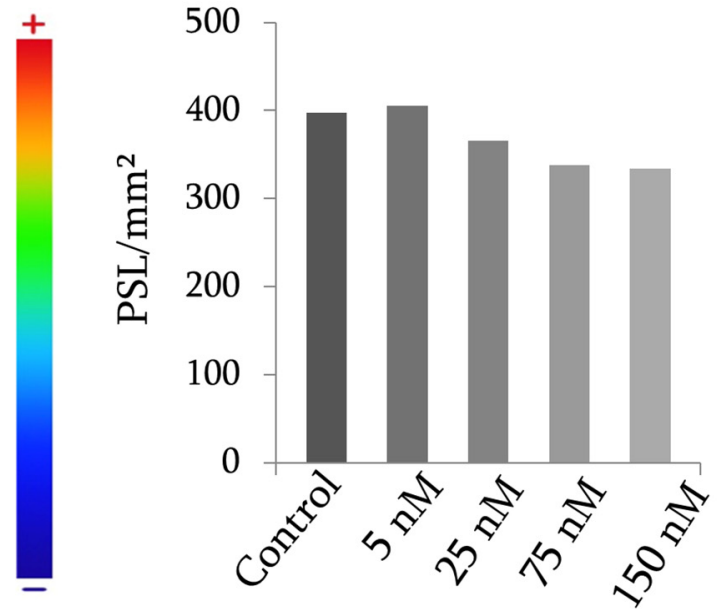

Figure 4. DASB is sensitive to serotonin concentration. Adjacent macaque coronal slices incubated with DASB and increasing concentrations of 5-HT. DASB labeling of the serotonin transporter decreases in a dose-dependent manner. Graph shows PSL values (mean of two duplicates) of the hippocampus.

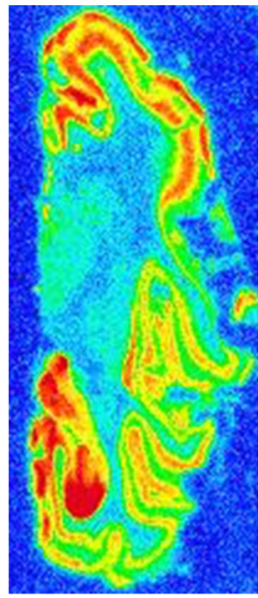

Control

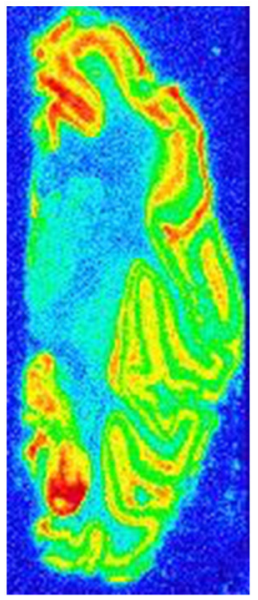

$5 \mathrm{ng}$

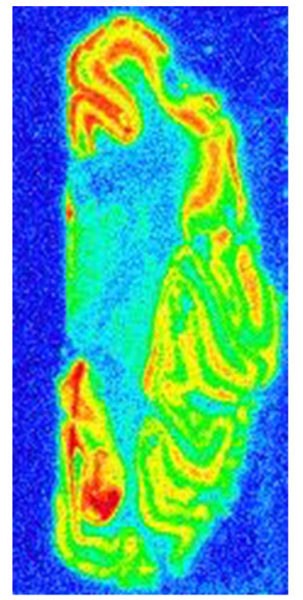

$100 \mathrm{ng}$

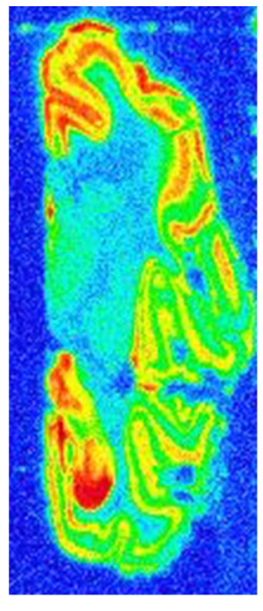

$2 \mu \mathrm{g}$

Figure 5. MPPF is insensitive to OT concentration. Adjacent macaque coronal slices incubated with MPPF and increasing concentrations of $0 \mathrm{~T}$ did not show any effects of $0 \mathrm{~T}$ on $5-\mathrm{HT}_{1 \mathrm{~A}}$-r MPPF labeling.

OT triggers serotonin release in the primate brain In the present experiment, we have found a decrease of $\left[{ }^{11} \mathrm{C}\right] \mathrm{DASB} \mathrm{BP}_{\mathrm{ND}}$. As it has been previously shown, OT can trigger 5-HT release (Dölen et al., 2013). Thus, a straightforward interpretation of the present finding is that OT has induced a release of serotonin. This hypothesis is consistent with our in vitro results, which suggest that $\left[{ }^{11} \mathrm{C}\right]$ DASB labeling is sensitive to endogenous serotonin concentration. However, given that OT was administered $45 \mathrm{~min}$ before scanning, an interpretation more coherent with this timing would be that the decrease of $\left[{ }^{11} \mathrm{C}\right] \mathrm{DASB}$ BPND more likely reflects SERT internalization consecutive to agonistic stimulation (Jørgensen et al., 2014). Thus, we propose that the main mechanism induced by OT within the 5 -HT system is a release of serotonin in the amygdala, insula, and hippocampus, and what we observed in the $\left[{ }^{11} \mathrm{C}\right]$ DASB PET-scan experiment could be the subsequent downregulation of SERT. Importantly, it seems that this effect is present only in selected brain regions. In vivo whole-brain analysis on $\left[{ }^{11} \mathrm{C}\right] \mathrm{DASB}$ scans corroborated in vitro results showing a modulation in the hippocampus but not in every single region rich in SERT.

This finding is of importance for several reasons. First, it indicates that OT triggers the release of 5-HT in a coordinated manner across many limbic areas in the primate's brain. Second, it points to the potential interactions between OT administration and the use of serotonergic drugs, such as selective serotonin reuptake inhibitor. Indeed, it is possible that OT potentiates the selective serotonin reuptake inhibitor effect. If so, this leads to a fascinating new area of research with combined OT and 5-HT drugs treatment in both animals' models of disease and patients, as both treatments are already FDA approved.

OT influences the serotonergic synapse Regarding the increased $\left[{ }^{18} \mathrm{~F}\right] \mathrm{MPPF}$ BPND and the decrease of $\left[{ }^{11} \mathrm{C}\right] \mathrm{DASB}$ BPND, measured here, we interpret this result as an increase of 5- $\mathrm{HT}_{1 \mathrm{~A}} \mathrm{R}$ availability. It is important to note that $\left[{ }^{18} \mathrm{~F}\right] \mathrm{MPPF}$ radiotracer is capable to detect only large pharmacological (nonphysiologic) variations of serotonin (Zimmer et al., 2002), but not endogenous modifications (Praschak-Rieder et al., 2004; Udo de Haes et al., 2006). This is because $\left[{ }^{18} \mathrm{~F}\right] \mathrm{MPPF}$ has a higher affinity for 5$\mathrm{HT}_{1 \mathrm{~A}} \mathrm{R}$ than endogenous serotonin and because $\left[{ }^{18} \mathrm{~F}\right] \mathrm{MPPF}$ is an antagonist and thus binds to both low- and high-affinity receptor states $\left(5-\mathrm{HT}_{1 \mathrm{~A}} \mathrm{R}\right.$ coupled or not to a $\mathrm{G}$ protein). In contrast, serotonin only binds to high affinity receptors (Kumar et al., 2012). Thus, we conclude that the present increase of $\left[{ }^{18} \mathrm{~F}\right] \mathrm{MPPF}$ BPND is due to an externalization of $5-\mathrm{HT}_{1 \mathrm{~A}} \mathrm{R}$, or a decoupling of these receptors from its $G$ protein following activa- 
tion, which could be a consequence of the serotonin release induced by OT. Following our in vitro results, we suggest that OT does not act directly on the $5-\mathrm{HT}_{1 \mathrm{~A}} \mathrm{R}$; therefore, the modulation we observed here could be a consequence of the 5-HT release.

Whether the in vivo effects we observed in the PET scan experiment are involving presynaptic or postsynaptic receptors is difficult to assess and requires further investigation.

These findings indicate that the activation of the serotonergic system by OT is more than a mere neurotransmitter release, but a phenomenon that has lasting, at least at middle term, consequences for the synapse. It is also important to mention that the modification of $5-\mathrm{HT}_{1 \mathrm{~A}} \mathrm{R}$ following the release of 5-HT may be a general mechanism, but this deserves further attention. The potential interactions of OT with serotonergic agent targeting the $5-\mathrm{HT}_{1 \mathrm{~A}} \mathrm{R}$ are hard to infer but seem a promising path of research.

\section{Limitations}

Some points in the present study need to be further addressed. For instance, the timing of OT injection did not allow us to study short-term effects of OT. However, studies generally found OT effects for dozens of minutes to hours, indicating that midterm action of OT could be responsible for these changes. It should also be noted that, because the PET scan signal emitted at the beginning of the scanning session is higher than the one at the end, our data are representing mostly the interval of time between 45 and $75 \mathrm{~min}$ after OT intracerebroventricular injection. Another point is the use of anesthetics, although the molecules we used (tiletamine, zolazepam) are known to have no influence on the serotonergic transporter (Elfving et al., 2003; Yamanaka et al., 2014). It is, however, less clear whether Zoletil can influence the $5-\mathrm{HT}_{1 \mathrm{~A}} \mathrm{R}$ directly or the OT system, although it has been observed that OT levels in plasma do not change after anesthesia (Nussey et al., 1988). Moreover, we did not find differences in CSF OT levels between anesthetized and conscious animals (A.L., manuscript in preparation). In contrast to our previous results in humans (Mottolese et al., 2014), we did not observe changes in the DRN. However, this could be explained by the difficulty to delimit this small structure in macaque monkeys. Notably, the atlas we used included the dorsal and median raphe nuclei as a single ROI because the resolution of PET-scan technique cannot properly distinguish these two regions (Ballanger et al., 2013). A surprising finding was that effects were localized to the right hemisphere. Although this is consistent with our study in humans, lateralization is not commonly observed in macaques, and this finding deserves further research. Such lateralization is often observed in fMRI-OT studies with humans (Domes et al., 2007; Kanat et al., 2015) but hard to interpret, especially because other studies have also found left lateralization (Kirsch et al., 2005). To increase the repeatability of our experiment and reduce brain damage caused by the needle, we always injected OT or PLA at the same location in the right hemisphere. This cannot be excluded as a contributing factor but is unlikely as the volume injected $(20 \mu \mathrm{l})$ should rapidly diffuse to the other hemisphere through the CSF flow. Finally, it is to note that OT receptors' distribution in the primate brain is not well understood; and although they have not been found in limbic areas of humans and macaques (Loup et al., 1991; Freeman et al., 2014; but see Boccia et al., 2013), administration of OT has consistently produced effects in these areas (Chang et al., 2015; Wigton et al., 2015). An alternative hypothesis could be that OT acts via other receptors, such as vasopressin 1A (Gupta et al., 2008; Schorscher-Petcu et al., 2010). Although this hypothesis cannot be completely ruled out, we think that the relatively low dose of OT used in the present study has prevented the activation of the vasopressin system. Also, another option would be the formation of OTR-5- $\mathrm{HT}_{1 \mathrm{~A}} \mathrm{R}$ heteromers, as such receptor complexes can change the affinity and trafficking of receptors (Bouvier, 2001; Ferré et al., 2009).

Finally, it might be that the effects of OT on 5-HT are contextdependent. Indeed, individuals' subjective state and the emotional context are probably powerful modulators of OT and 5 -HT interplay. Gender is another factor that could have a role here given the differences of OT neuroendocrine system organization among males and females. Unfortunately, although this is a factor that could not be explored here, we think it should be taken into account in future studies exploring effects of OT on 5-HT.

In conclusion, the present work brings new evidence showing that OT modulates the serotonergic system in the primate brain. This modulation occurs in cerebral structures important for social behaviors. Thus, a potential mechanism is that OT provokes the release of serotonin, which in turn changes $5-\mathrm{HT}_{1 \mathrm{~A}} \mathrm{R}$ functioning. This finding can have an important impact for pharmaceutic research, as OT, 5- $\mathrm{HT}_{1 \mathrm{~A}} \mathrm{R}$, and SERT are all important targets in several pathologies, including depression, autism, and general anxiety (Bandelow et al., 2002; Celada et al., 2013; Vasa et al., 2014). Thus, studying the interaction between these systems could be a critical step toward improved psychiatric treatments.

\section{References}

Altirriba J, Poher AL, Rohner-Jeanrenaud F (2015) Chronic oxytocin administration as a treatment against impaired leptin signaling or leptin resistance in obesity. Front Endocrinol 6:119. CrossRef Medline

Amico JA, Levin SC, Cameron JL (1989) Circadian rhythm of oxytocin in the cerebrospinal fluid of rhesus and cynomolgus monkeys: effects of castration and adrenalectomy and presence of a caudal-rostral gradient. Neuroendocrinology 50:624-632. Medline

Ballanger B, Tremblay L, Sgambato-Faure V, Beaudoin-Gobert M, Lavenne F, Le Bars D, Costes N (2013) A multi-atlas based method for automated anatomical Macaca fascicularis brain MRI segmentation and PET kinetic extraction. Neuroimage 77:26-43. CrossRef Medline

Bandelow B, Zohar J, Hollander E, Kasper S, Möller HJ (2002) World Federation of Societies of Biological Psychiatry (WFSBP) guidelines for the pharmacological treatment of anxiety, obsessive-compulsive and posttraumatic stress disorders. World J Biol Psychiatry 3:171-199. CrossRef Medline

Baskerville TA, Douglas AJ (2010) Dopamine and oxytocin interactions underlying behaviors: potential contributions to behavioral disorders. CNS Neurosci Ther 16:e92-e123. CrossRef Medline

Boccia ML, Petrusz P, Suzuki K, Marson L, Pedersen CA (2013) Immunohistochemical localization of oxytocin receptors in human brain. Neuroscience 253:155-164. CrossRef Medline

Bosch OJ, Dabrowska J, Modi ME, Johnson ZV, Keebaugh AC, Barrett CE, Ahern TH, Guo J, Grinevich V, Rainnie DG, Neumann ID, Young LJ (2016) Oxytocin in the nucleus accumbens shell reverses CRFR2-evoked passive stress-coping after partner loss in monogamous male prairie voles. Psychoneuroendocrinology 64:66-78. CrossRef Medline

Bouvier M (2001) Oligomerization of G-protein-coupled transmitter receptors. Nat Rev Neurosci 2:274-286. Medline

Celada P, Bortolozzi A, Artigas F (2013) Serotonin 5-HT1A receptors as targets for agents to treat psychiatric disorders: rationale and current status of research. CNS Drugs 27:703-716. CrossRef Medline

Chang SWC, Fagan NA, Toda K, Utevsky AV, Pearson JM, Platt ML (2015) Neural mechanisms of social decision-making in the primate amygdala. Proc Natl Acad Sci U S A 112:16012-16017. Medline

Collins DL, Neelin P, Peters TM, Evans AC (1994) Automatic 3D intersubject registration of MR volumetric data in standardized Talairach space. J Comput Assist Tomogr 18:192-205. CrossRef Medline

Dabrowska J, Hazra R, Ahern TH, Guo JD, McDonald AJ, Mascagni F, Muller JF, Young LJ, Rainnie DG (2011) Neuroanatomical evidence for recip- 
rocal regulation of the corticotrophin-releasing factor and oxytocin systems in the hypothalamus and the bed nucleus of the stria terminalis of the rat: implications for balancing stress and affect. Psychoneuroendocrinology 36:1312-1326. CrossRef Medline

Dölen G, Darvishzadeh A, Huang KW, Malenka RC (2013) Social reward requires coordinated activity of nucleus accumbens oxytocin and serotonin. Nature 501:179-184. CrossRef Medline

Domes G, Heinrichs M, Gläscher J, Büchel C, Braus DF, Herpertz SC (2007) Oxytocin attenuates amygdala responses to emotional faces regardless of valence. Biol Psychiatry 62:1187-1190. CrossRef Medline

Elfving B, Bjørnholm B, Knudsen GM (2003) Interference of anaesthetics with radioligand binding in neuroreceptor studies. Eur J Nucl Med Mol Imaging 30:912-915. CrossRef Medline

Eliava M, Melchior M, Knobloch-Bollmann HS, Wahis J, da Silva Gouveia M, Tang Y, Ciobanu AC, Triana del Rio R, Roth LC, Althammer F, Chavant V, Goumon Y, Gruber T, Petit-Demoulière N, Busnelli M, Chini B, Tan LL, Mitre M, Froemke RC, Chao MV, et al. (2016) A new population of parvocellular oxytocin neurons controlling magnocellular neuron activity and inflammatory pain processing. Neuron 89:1291-1304. CrossRef Medline

Febo M, Ferris CF (2014) Oxytocin and vasopressin modulation of the neural correlates of motivation and emotion: results from functional MRI studies in awake rats. Brain Res 1580:8-21. CrossRef Medline

Feifel D, Shilling PD, MacDonald K (2016) A review of oxytocin's effects on the positive, negative, and cognitive domains of schizophrenia. Biol Psychiatry 79:222-233. CrossRef Medline

Ferré S, Baler R, Bouvier M, Caron MG, Devi LA, Durroux T, Fuxe K, George SR, Javitch JA, Lohse MJ, Mackie K, Milligan G, Pfleger KDG, Pin J-P, Volkow ND, Waldhoer M, Woods AS, Franco R (2009) Building a new conceptual framework for receptor heteromers. Nat Chem Biol 5:131134. CrossRef Medline

Freeman SM, Inoue K, Smith AL, Goodman MM, Young LJ (2014) The neuroanatomical distribution of oxytocin receptor binding and mRNA in the male rhesus macaque (Macaca mulatta). Psychoneuroendocrinology 45:128-141. CrossRef Medline

Gupta J, Russell R, Wayman C, Hurley D, Jackson V (2008) Oxytocininduced contractions within rat and rabbit ejaculatory tissues are mediated by vasopressin V1A receptors and not oxytocin receptors. $\mathrm{Br} \mathrm{J}$ Pharmacol 155:118-126. CrossRef Medline

Hamon M, Gozlan H, el Mestikawy S, Emerit MB, Bolaños F, Schechter L (1990) The central 5-HT1A receptors: pharmacological, biochemical, functional, and regulatory properties. Ann N Y Acad Sci 600:114-129; discussion 129-131. CrossRef Medline

Jørgensen TN, Christensen PM, Gether U (2014) Serotonin-induced downregulation of cell surface serotonin transporter. Neurochem Int 73:107112. CrossRef Medline

Kanat M, Heinrichs M, Schwarzwald R, Domes G (2015) Oxytocin attenuates neural reactivity to masked threat cues from the eyes. Neuropsychopharmacology 40:287-295. CrossRef

Kirsch P, Esslinger C, Chen Q, Mier D, Lis S, Siddhanti S, Gruppe H, Mattay VS, Gallhofer B, Meyer-Lindenberg A (2005) Oxytocin modulates neural circuitry for social cognition and fear in humans. J Neurosci 25:1148911493. CrossRef Medline

Knobloch HS, Charlet A, Hoffmann LC, Eliava M, Khrulev S, Cetin AH, Osten P, Schwarz MK, Seeburg PH, Stoop R, Grinevich V (2012) Evoked axonal oxytocin release in the central amygdala attenuates fear response. Neuron 73:553-566. CrossRef Medline

Kovács B, Kéri S (2015) Off-label intranasal oxytocin use in adults is associated with increased amygdala-cingulate resting-state connectivity. Eur Psychiatry 30:542-547. CrossRef Medline

Kumar JSD, Milak MS, Majo VJ, Prabhakaran J, Mali P, Savenkova L, Mann JJ, Parsey RV (2012) Comparison of high and low affinity serotonin 1A receptors by PET in vivo in nonhuman primates. J Pharmacol Sci 120: $254-257$.

Le Bars D, Lemaire C, Ginovart N, Plenevaux A, Aerts J, Brihaye C, Hassoun W, Leviel V, Mekhsian P, Weissmann D, Pujol JF, Luxen A, Comar D (1998) High-yield radiosynthesis and preliminary in vivo evaluation of p- $\left[{ }^{18} \mathrm{~F}\right] \mathrm{MPPF}$, a fluoro analog of WAY-100635. Nucl Med Biol 25:343350. CrossRef Medline

Lefevre A, Sirigu A (2016) The two fold role of oxytocin in social developmental disorders: a cause and a remedy? Neurosci Biobehav Rev 63:168176. CrossRef Medline
Leng G, Ludwig M (2016) Intranasal oxytocin: myths and delusions. Biol Psychiatry 79:243-250. CrossRef Medline

Loup F, Tribollet E, Dubois-Dauphin M, Dreifuss JJ (1991) Localization of high-affinity binding sites for oxytocin and vasopressin in the human brain. An autoradiographic study. Brain Res 555:220-232.

Lundquist P, Roman M, Syvänen S, Hartvig P, Blomquist G, HammarlundUdenaes M, Långström B (2007) Effect on $\left[{ }^{11} \mathrm{C}\right]$ DASB binding after tranylcypromine-induced increase in serotonin concentration: positron emission tomography studies in monkeys and rats. Synapse 61:440 -449. CrossRef Medline

Marlin BJ, Mitre M, D'amour JA, Chao MV, Froemke RC (2015) Oxytocin enables maternal behaviour by balancing cortical inhibition. Nature 520 : 499-504. CrossRef Medline

McCall C, Singer T (2012) The animal and human neuroendocrinology of social cognition, motivation and behavior. Nat Neurosci 15:681-688. CrossRef Medline

Mottolese R, Redouté J, Costes N, Le Bars D, Sirigu A (2014) Switching brain serotonin with oxytocin. Proc Natl Acad Sci U S A 111:8637-8642. CrossRef Medline

Nakajima M, Görlich A, Heintz N (2014) Oxytocin modulates female sociosexual behavior through a specific class of prefrontal cortical interneurons. Cell 159:295-305. CrossRef Medline

Nussey SS, Page SR, Ang VTY, Jenkins JS (1988) The response of plasma oxytocin to surgical stress. Clin Endocrinol (Oxf) 28:277-288. CrossRef Medline

Oettl LL, Ravi N, Schneider M, Scheller MF, Schneider P, Mitre M, da Silva Gouveia M, Froemke RC, Chao MV, Young WS, Meyer-Lindenberg A, Grinevich V, Shusterman R, Kelsch W (2016) Oxytocin enhances social recognition by modulating cortical control of early olfactory processing. Neuron 90:609-621. CrossRef Medline

Owen SF, Tuncdemir SN, Bader PL, Tirko NN, Fishell G, Tsien RW (2013) Oxytocin enhances hippocampal spike transmission by modulating fastspiking interneurons. Nature 500:458-462. CrossRef Medline

Pagani JH, Williams Avram SK, Cui Z, Song J, Mezey É, Senerth JM, Baumann MH, Young WS (2015) Raphe serotonin neuron-specific oxytocin receptor knockout reduces aggression without affecting anxiety-like behavior in male mice only. Genes Brain Behav 14:167-176. CrossRef Medline

Paxinos G, Huang X-F, Toga A (2000) The rhesus monkey brain in stereotaxic coordinates. Fac Health Behav Sci - Pap Arch. Available at: http://ro.uow. edu.au/hbspapers/3613.

Pedersen CA, Ascher JA, Monroe YL, Prange AJ Jr (1982) Oxytocin induces maternal behavior in virgin female rats. Science 216:648-650. CrossRef Medline

Praschak-Rieder N, Hussey D, Wilson AA, Carella A, Lee M, Dunn E, Willeit M, Bagby RM, Houle S, Meyer JH (2004) Tryptophan depletion and serotonin loss in selective serotonin reuptake inhibitor-treated depression: an $\left[{ }^{18} \mathrm{~F}\right]$ MPPF positron emission tomography study. Biol Psychiatry 56:587-591. CrossRef Medline

Savli M, Bauer A, Mitterhauser M, Ding YS, Hahn A, Kroll T, Neumeister A, Haeusler D, Ungersboeck J, Henry S, Isfahani SA, Rattay F, Wadsak W, Kasper S, Lanzenberger R (2012) Normative database of the serotonergic system in healthy subjects using multi-tracer PET. Neuroimage 63 : 447-459. CrossRef Medline

Schorscher-Petcu A, Sotocinal S, Ciura S, Dupré A, Ritchie J, Sorge RE, Crawley JN, Hu SB, Nishimori K, Young LJ, Tribollet E, Quirion R, Mogil JS (2010) Oxytocin-induced analgesia and scratching are mediated by the vasopressin-1A receptor in the mouse. J Neurosci 30:8274-8284. CrossRef Medline

Sripada CS, Phan KL, Labuschagne I, Welsh R, Nathan PJ, Wood AG (2013) Oxytocin enhances resting-state connectivity between amygdala and medial frontal cortex. Int J Neuropsychopharmacol 16:255-260. CrossRef Medline

Udo de Haes JI, Harada N, Elsinga PH, Maguire RP, Tsukada H (2006) Effect of fenfluramine-induced increases in serotonin release on $\left[{ }^{18} \mathrm{~F}\right] \mathrm{MPPF}$ binding: a continuous infusion PET study in conscious monkeys. Synap N Y N 59:18-26.

Vasa RA, Carroll LM, Nozzolillo AA, Mahajan R, Mazurek MO, Bennett AE, Wink LK, Bernal MP (2014) A systematic review of treatments for anxiety in youth with autism spectrum disorders. J Autism Dev Disord 44: 3215-3229. CrossRef Medline 
Viviani D, Charlet A, van den Burg E, Robinet C, Hurni N, Abatis M, Magara F, Stoop R (2011) Oxytocin selectively gates fear responses through distinct outputs from the central amygdala. Science 333:104-107. CrossRef Medline

Wigton R, Radua J, Allen P, Averbeck B, Meyer-Lindenberg A, McGuire P, Shergill SS, Fusar-Poli P (2015) Neurophysiological effects of acute oxytocin administration: systematic review and meta-analysis of placebocontrolled imaging studies. J Psychiatry Neurosci 40:E1-E22. CrossRef Medline

Yamanaka H, Yokoyama C, Mizuma H, Kurai S, Finnema SJ, Halldin C, Doi $\mathrm{H}$, Onoe $\mathrm{H}$ (2014) A possible mechanism of the nucleus accumbens and ventral pallidum 5-HT1B receptors underlying the antidepressant action of ketamine: a PET study with macaques. Transl Psychiatry 4:e342. CrossRef Medline

Yoshida M, Takayanagi Y, Inoue K, Kimura T, Young LJ, Onaka T, Nishimori K (2009) Evidence that oxytocin exerts anxiolytic effects via oxytocin receptor expressed in serotonergic neurons in mice. J Neurosci 29:22592271. CrossRef Medline

Young LJ, Wang Z (2004) The neurobiology of pair bonding. Nat Neurosci 7:1048-1054. CrossRef Medline

Zimmer L, Mauger G, Le Bars D, Bonmarchand G, Luxen A, Pujol J-F (2002) Effect of endogenous serotonin on the binding of the 5-hT1A PET ligand $18 \mathrm{~F}-\mathrm{MPPF}$ in the rat hippocampus: kinetic beta measurements combined with microdialysis. J Neurochem 80:278-286. CrossRef Medline 